\title{
Effect of Depth of Lime Application on Yield and Foliar Composition of Soybeans Grown on a Typical Ultisol of Puerto Rico ${ }^{1,2}$
}

\author{
Raúl Pérez-Escolar, M. A. Lugo-López, and T. W. Scott ${ }^{3}$ \\ ABSTRACT
}

The effects of lime applied at 20,40 , and $60 \mathrm{~cm}$ depths, and calcium nitrate applied in the top $20 \mathrm{~cm}$, in terms of yield of two soybean crops, Jupiter variety, and on the factors of soil acidity in Humatas clay (a typical upland Ultisol of Puerto Rico) were determined. Highly significant and significant correlations between soybean yield and factors of soil acidity of the topmost $60 \mathrm{~cm}$ of the soil profile were measured in the first and second crops, respectively. A straight line equation best described the results. As long as 33 months following the lime application in treatments bearing lime in the top $20 \mathrm{~cm}$ layer, increases of soil pH and bases and subsequent decreases in the exchangeable aluminum content of the 20 to $40 \mathrm{~cm}$ layer beneath were evident and indicative of lime movement.

\section{INTRODUCTION}

The behavior of lime applied to soils of the humid tropics has been intriguing and the subject of much study. Not much information seems to be available about deep liming of soils in this part of the world. Beneficial effects might be obtained from this practice, since deep-rooted crops can make efficient use of moisture and nutrients stored deep in the soil profile. Pérez-Escolar et al. $^{4}$ recently measured the effects of lime applied at $0-20,0-40$, and $0-60 \mathrm{~cm}$ depths and calcium nitrate in the top $20 \mathrm{~cm}$ on yields of two corn hybrids and on the factors of soil acidity in a typical upland Ultisol of Puerto Rico. The inactivation of ionic aluminum, particularly at lower depths, allowing soil moisture to be absorbed at its highest degree, appeared to be the main cause of higher yields.

This paper reports on subsequent experiments with soybeans using the same plots on which the previous four corn crops were grown. The objectives were to measure the effects of $\mathrm{pH}$ and factors of soil acidity on yield and foliar composition of soybeans as affected by depth of lime applications.

\footnotetext{
${ }^{1}$ Manuscript submitted to Editorial Board November 1, 1977.

${ }^{2}$ Joint contribution from Department of Agronomy, Cornell University, Ithaca, N.Y., and Agricultural Experiment Station, University of Puerto Rico, Mayagüez Campus, Mayagüez, P.R. This study was part of the investigations supported by USAID under research contract ta-c-1104 entitled "Soil Fertility in the Humid Tropics".

${ }^{3}$ Soil Scientist, Agricultural Experiment Station, University of Puerto Rico, Mayagüez Campus; Consultant, and Professor of Soil Science, Cornell University, Ithaca, N.Y.

${ }^{4}$ Pérez-Escolar, Raúl, and Lugo-López, M. A., 1978. Effect of depth of lime application on the yield of two corn hybrids grown on a typical Ultisol of Puerto Rico, J. Agric. Univ. P.R. 62(3): 203-13.
} 


\section{MATERIALS AND METHODS}

Details about site, soil properties, treatments, and experimental design are summarized as follows: 1) Site, Orocovis, P.R., upland, northern exposure, $450 \mathrm{~m}$ above sea level, humid; 2) soil, Humatas clay, an Ultisol, Typic Tropohumults, clayey, kaolinitic, isohyperthermic; 3) $\mathrm{pH}, 4.8$; 4) exchangeable Al, $4.0 \mathrm{meq} / 100 \mathrm{~g}$ of soil; 5) C.E.C., $10 \mathrm{meq} / 100 \mathrm{~g}$ of soil; 6) experimental design, randomized blocks with 7 treatments, a) no lime, profile disturbed to $60 \mathrm{~cm}$; b) lime $0-20 \mathrm{~cm}$, profile disturbed to $60 \mathrm{~cm}$; c) lime 0-40 cm, profile disturbed to $60 \mathrm{~cm}$; d) lime $60 \mathrm{~cm}$, profile disturbed to $60 \mathrm{~cm}$; e) no lime, top $20 \mathrm{~cm}$ disturbed; f) $\mathrm{Ca}\left(\mathrm{NO}_{3}\right)_{2}{ }^{5}$, top $20 \mathrm{~cm}$ disturbed; g) lime + urea, topmost $20 \mathrm{~cm}$ disturbed. For each meq of exchangeable $\mathrm{Al}, 3$ meq of $\mathrm{Ca}$ as $\mathrm{Ca}(\mathrm{OH})_{2}$ were added as required according to liming treatments.

The first soybean crop, variety Jupiter, was planted February 3, 1976, a day after the application of a mixture of $112 \mathrm{~kg} / \mathrm{ha}$ of $\mathrm{P}_{2} \mathrm{O}_{5}$ as triple superphosphate, $67 \mathrm{~kg} / \mathrm{ha}$ of $\mathrm{K}_{2} \mathrm{O}$ as $\mathrm{K}_{2} \mathrm{SO}_{4}$, and $56 \mathrm{~kg} / \mathrm{ha}$ of $\mathrm{Mg}$ as Epsom salt. Except for the $\mathrm{Ca}\left(\mathrm{NO}_{3}\right)_{2}$ treatment, the plots which received $\mathrm{N}$ at a rate of $224 \mathrm{~kg} / \mathrm{ha}$ in split applications (one before planting time and another immediately after budding), the rest of the treatments received no $N$, since the soybean seeds were inoculated with Nitragin "S". ${ }^{6}$ Just before budding, the number 3 leaf was sampled for $\mathrm{N}, \mathrm{P}, \mathrm{K}, \mathrm{Ca}, \mathrm{Mg}$, and Mn determination. The soybean crop was harvested July 15, 1976, 51/2 months after planting. A week later, soil samples from the 0-20, 20-40, and 40-60 $\mathrm{cm}$ depths were taken from all plots, and $\mathrm{pH}$, exchangeable $\mathrm{Ca}, \mathrm{Mg}$ and $\mathrm{Al}$ determined in order to measure relations, if any, between crop yield and soil acidity parameters.

The second soybean crop was planted September 2, 1976. The procedures described for the first crop were followed for the second crop, except that it was harvested 3 months after planting; little more than half the time was required for maturity than for the first crop, probably because the period of growth and development of the second crop fell in the midst of a short-day period. A rainfall gauge was installed near the experiment and the corresponding data were collected during the course of the experiments.

Both analysis of variance and Duncan's test were used to determine differences, if any, among treatments. Whenever relations among yield, foliar composition, and soil acidity parameters were apparent, regression

${ }^{5} \mathrm{The} \mathrm{Ca}\left(\mathrm{NO}_{3}\right)_{2}$ treatment consisted of adding enough of the salt to provide $224 \mathrm{~kg} / \mathrm{ha}$ of $\mathrm{N}$ and consequently $350 \mathrm{~kg} / \mathrm{ha}$ of $\mathrm{Ca}$.

${ }^{6}$ Trade names are used in this publication solely for the purpose of providing specific information. Mention of a trade name does not constitute a guarantee or warranty of equipment or materials by the Agricultural Experiment Station of the University of Puerto Rico or an endorsement over other equipment or materials not mentioned. 
analyses were run and the corresponding equations developed. Relationships between the yields and the acidity indexes for both experiments were run against the soil samples taken between the first and second soybean crop.

\section{RESULTS AND DISCUSSION}

Table 1 shows the effect of depth of lime application and surface application of calcium nitrate on the yield and leaf chemical composition of Jupiter variety soybeans grown on a Humatas clay, an Ultisol. Statis-

TABLE 1.-The effect of depth of lime application and surface application of calcium nitrate on yield and on leaf chemical composition of soybean, Jupiter variety, grown on a Humatas clay, an Ultisol

\begin{tabular}{|c|c|c|c|c|c|c|c|}
\hline \multirow{2}{*}{ Treatment } & \multirow{2}{*}{ Yield $^{1}$} & \multicolumn{6}{|c|}{ Foliar composition } \\
\hline & & $\mathrm{N}$ & P & K & $\mathrm{Ca}$ & $\mathrm{Mg}$ & $\mathrm{Mn}$ \\
\hline & $K g / h a$ & & & $\%$ & & & \\
\hline \multicolumn{8}{|c|}{ First soybean crop } \\
\hline 1. No lime ${ }^{2}$ & $1,327 \mathrm{a}$ & 4.80 & 0.13 & 1.79 & 0.63 & 0.42 & 136 \\
\hline 2. Lime, $0-20 \mathrm{~cm}$ & $1,879 a b$ & 5.01 & .19 & 1.70 & $.81^{* 3}$ & .35 & 85 \\
\hline 3. Lime, $0-40 \mathrm{~cm}$ & $1,974 \mathrm{ab}$ & 4.83 & .15 & 1.58 & $.79^{*}$ & .41 & 70 \\
\hline 4. Lime, 0-60 cm & $2,520 \mathrm{~b}$ & 4.92 & .14 & 1.75 & $.87^{* *}$ & .43 & 78 \\
\hline 5. No lime $e^{4}$ & 1,431 a & 4.69 & .13 & 1.63 & .71 & .45 & 125 \\
\hline 6. $\mathrm{Ca}\left(\mathrm{NO}_{3}\right)_{2}$ & $1,776 \mathrm{ab}$ & 4.51 & .14 & 1.65 & .59 & .38 & 90 \\
\hline 7. Lime + urea & $1,722 \mathrm{ab}$ & 4.31 & .15 & 1.59 & $.80^{*}$ & .45 & 101 \\
\hline \multicolumn{8}{|c|}{ Second soybean crop } \\
\hline 1. No lime ${ }^{1}$ & $1,388 \mathrm{a}$ & 4.91 & 0.13 & 2.30 & 0.99 & 0.91 & 422 \\
\hline 2. Lime, $0-20 \mathrm{~cm}$ & $1,602 \mathrm{a}$ & 4.65 & .13 & 1.88 & $1.57^{* 5}$ & .95 & 262 \\
\hline 3. Lime, $0-40 \mathrm{~cm}$ & $1,843 \mathrm{a}$ & 4.92 & .11 & 1.64 & $1.59^{*}$ & 1.02 & 215 \\
\hline 4. Lime, $0-60 \mathrm{~cm}$ & 1,626 a & 4.86 & .12 & 1.77 & $1.46^{*}$ & .99 & 241 \\
\hline 5. No lime ${ }^{2}$ & $1,319 \mathrm{a}$ & 5.01 & .14 & 2.00 & 1.15 & .97 & 390 \\
\hline 6. $\mathrm{Ca}\left(\mathrm{NO}_{3}\right)_{2}$ & $1,689 \mathrm{a}$ & 4.95 & .15 & 2.17 & 1.26 & 1.01 & 279 \\
\hline 7. Lime + urea & $2,100 \mathrm{a}$ & 4.79 & .13 & 1.95 & $1.47^{*}$ & .96 & 311 \\
\hline
\end{tabular}

${ }^{1}$ Coefficient of variation 32.5437 and 35.8454 for first and second crop, respectively.

${ }^{2}$ Disturbed profile down to $60 \mathrm{~cm}$ depth.

${ }^{3}$ First crop: * significant over treatments 1, 6; ** highly significant over 1, 6 .

${ }^{4}$ Only top $20 \mathrm{~cm}$ soil profile disturbed.

${ }^{5}$ Second crop: * significant over treatments 1, 5.

tically significant differences in yield were measured only between the 0-60 cm lime treatment and both check treatments. Except for percent calcium absorbed by the crop, no statistically significant differences were measured with respect to the rest of the nutrient ions. There was no difference in the percent calcium absorbed by treatments bearing lime, irrespective of the depth to which it was added.

When regression analyses were run to quantify the effects of soil acidity indexes of the $0-60 \mathrm{~cm}$ soil profile on soybean yield, highly significant correlation coefficients were obtained, as shown in figures 1, A through 

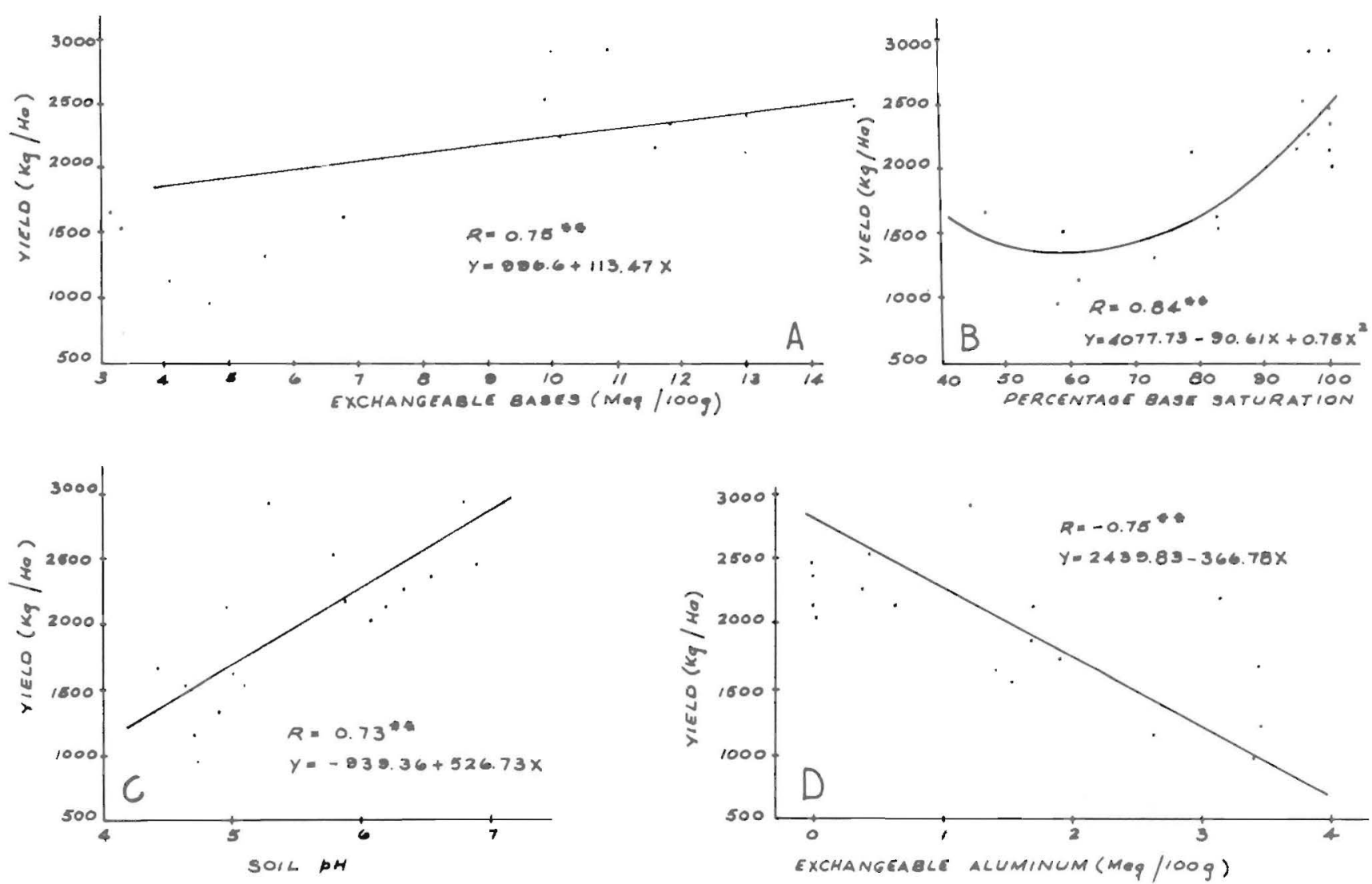

FIG. 1.-A, Relationship between exchangeable bases and soybean yield; B, Relationship between percentage base saturation and yield; $\mathrm{C}$, Relationship between soil $\mathrm{pH}$ and yield;

$\mathrm{D}$, Relationship between exchangeable aluminum and yield. 
D. Except for the percent base saturation parameter, which was quadratic, the others, such as soil $\mathrm{pH}$, exchangeable $\mathrm{Ca}+\mathrm{Mg}$, and exchangeable Al, exhibited linear relationships to crop yield. The highest $\mathrm{pH}$ range, higher than 6.2 , as shown in table 2 , yielded $73 \%$ more than the lowest $\mathrm{pH}$ range, 4.4 to 5.0 ; the highest exchangeable bases range, greater than $12 \mathrm{meq} / 100 \mathrm{~g}, 68 \%$ more than $3-6$ base range; the lowest exchangeable Al range $(0-1 \mathrm{meq} / 100 \mathrm{~g})$ yielded $77 \%$ more than the high range (greater than $3 \mathrm{meq} / 100 \mathrm{~g}$ ). A $62 \%$ yield increase was obtained for the $80-100$ base percent saturation range above the $40-60 \%$ range.

In the second soybean crop, no statistically significant differences were

TABLE 2.-The effect of soil $\mathrm{pH}$ and related acidity factors of top $60 \mathrm{~cm}$ of soil on yield of soybeans grown on a Humatas clay, an Ultisol

\begin{tabular}{ccc}
\hline Acidity indices ranges & Crop 1 & Crop 2 \\
\hline Soil $p H$ & $K g / h a$ & $K g / h a$ \\
$4.4-5.0$ & 1,459 & 1,464 \\
$5.0-5.6$ & 2,023 & 1,567 \\
$5.6-6.2$ & 2,209 & 2,015 \\
$>6.2$ & 2,520 & 1,767 \\
Exchangeable Ca + Mg & & \\
Meq/100 g & 1,327 & 1,169 \\
$3-6$ & 1,758 & 1,285 \\
$6-9$ & 2,503 & 2,064 \\
$9-12$ & 2,227 & 1,665 \\
$>12$ & & \\
Exchangeable Al & 2,365 & 1,888 \\
Meq/100g & 1,899 & 1,712 \\
$0-1$ & 1,329 & 1,385 \\
$1-2$ & 1,334 & 954 \\
$2-3$ & 1,396 & 1,200 \\
$>3$ & 1,521 & 1,534 \\
$40-60$ & 2,262 & 1,735 \\
\hline $80-80$ & &
\end{tabular}

found among treatments. However, when regression studies between soil acidity factors and crop yield were run, significant correlation coefficients were obtained, (figures 2, E through G). The lower correlation coefficient values could possibly be because the second soybean crop yields were correlated with soil samples collected after the first soybean crop, several weeks before the second crop was planted.

The linear effects measured in che first sovbean crop can probably be explained on the basis of the rather scant rainfall $(343 \mathrm{~mm})$ during 105 days of marked evapotranspiration. The top $60 \mathrm{~cm}$ of soil profile in the beginning had an available moisture content of $80 \mathrm{~mm}$, producing an 

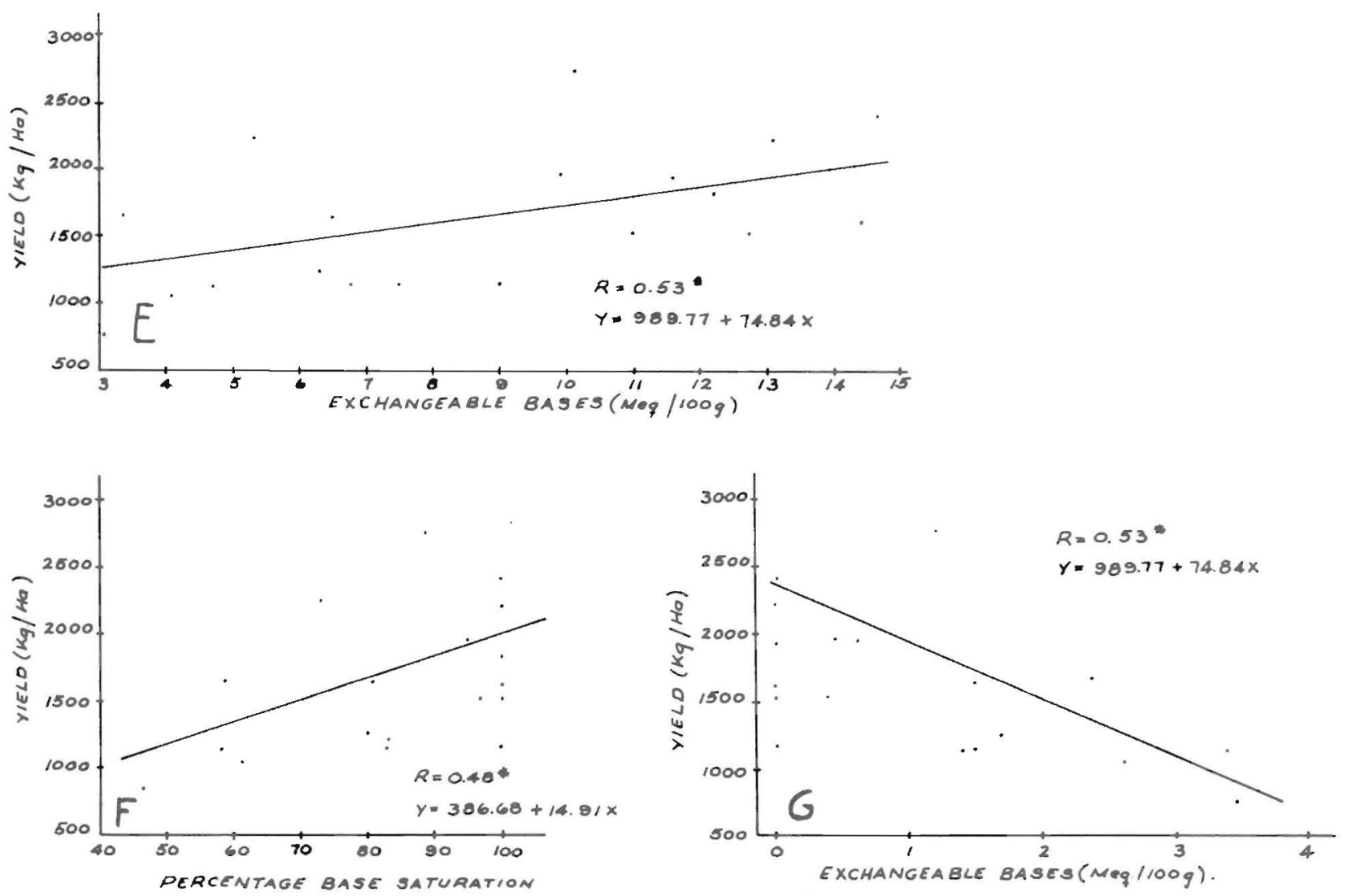

FIG. 2.-E, Relationship between exchangeable bases and yield; F, Relationship between percentage base saturation and yield; G, Relationship between exchangeable aluminum and yield. 
equivalent of about $423 \mathrm{~mm}$ of rainfall. Assuming that a soybean crop evapotranspires $6.35 \mathrm{~mm} /$ day, which is a common value for many crops in the tropics, the crop would have required a total of $667 \mathrm{~mm}$ of available water.

It is difficult to account for the linear effects measured in the second soybean crop in which $673 \mathrm{~mm}$ of rainfall were registered and the top 60 $\mathrm{cm}$ of soil profile had enough moisture to supply the crop for 30 days

TABLE 3.-Soil chemical data between first and second soybean crops (33 months following lime application)

\begin{tabular}{|c|c|c|c|}
\hline $\begin{array}{l}\text { Treatment and depth of } \\
\text { sampling, } \mathrm{cm}\end{array}$ & $\mathrm{pH}$ & $\begin{array}{l}\text { Exchangeable bases } \\
\text { meq/100 g }\end{array}$ & $\begin{array}{l}\text { Exchangeable Al } \\
\text { meq } / 100 \mathrm{~g}\end{array}$ \\
\hline \multicolumn{4}{|l|}{ Check, disturbed } \\
\hline $0-20$ & 4.62 & 5.19 & 2.89 \\
\hline $20-40$ & 4.74 & 3.01 & 2.58 \\
\hline $40-60$ & 4.72 & 3.17 & 2.78 \\
\hline \multicolumn{4}{|l|}{ Lime, $0-20$} \\
\hline $0-20$ & 5.56 & 9.62 & 0.13 \\
\hline $20-40$ & 4.81 & 7.02 & 1.92 \\
\hline $40-60$ & 4.79 & 5.23 & 2.38 \\
\hline \multicolumn{4}{|l|}{ Lime, $0-40$} \\
\hline $0-20$ & 5.60 & 10.31 & 0 \\
\hline $20-40$ & 6.95 & 13.26 & 0 \\
\hline $40-60$ & 5.14 & 9.23 & 0.66 \\
\hline \multicolumn{4}{|l|}{ Lime, $0-60$} \\
\hline $0-20$ & 5.70 & 9.66 & 0.23 \\
\hline $20-40$ & 6.80 & 12.43 & 0 \\
\hline $40-60$ & 7.34 & 15.19 & 0 \\
\hline \multicolumn{4}{|l|}{ Check, undisturbed } \\
\hline $0-20$ & 4.71 & 5.04 & 2.69 \\
\hline $20-40$ & 4.68 & 3.63 & 3.20 \\
\hline $40-60$ & 4.65 & 2.93 & 3.28 \\
\hline \multicolumn{4}{|l|}{$\mathrm{Ca}\left(\mathrm{NO}_{3}\right)_{2}$} \\
\hline $0-20$ & 4.95 & 6.82 & 1.33 \\
\hline $20-40$ & 4.79 & 4.40 & 2.28 \\
\hline $40-60$ & 4.83 & 3.13 & 2.59 \\
\hline \multicolumn{4}{|l|}{ Lime + Urea } \\
\hline $0-20$ & 5.27 & 8.45 & 0.71 \\
\hline $20-40$ & 4.84 & 6.21 & 2.07 \\
\hline $40-60$ & 4.80 & 5.12 & 2.76 \\
\hline
\end{tabular}

after planting. For this reason, one would expect that, unless a poor distribution of rainfall occurred during the greatest growth and grainfilling period, the moisture available in the top $20 \mathrm{~cm}$ of soil should have been enough to produce optimum yields and the crop did not need to go deeper to utilize it.

Table 3 shows the soil chemical characteristics of the top $60 \mathrm{~cm}$ of the soil profile after the first soybean crop harvest. Both check treatments 
(disturbed and undisturbed) remain as expected, acid with a corresponding rather high exchangeable $\mathrm{Al}$ content. $\mathrm{A}$ slight $\mathrm{pH}$ increase with a subsequent base increase and $\mathrm{Al}$ decrease in the 20 to $40 \mathrm{~cm}$ layer had been registered in the $0-20 \mathrm{~cm}$ lime treatment, indicative of movement of lime.

At this time, the $\mathrm{Ca}\left(\mathrm{NO}_{3}\right)_{2}$ treatment seems to have exerted some favorable influence on the soil $\mathrm{pH}$ of the top $0-20 \mathrm{~cm}$ profile and on the base status of the top $40 \mathrm{~cm}$. The exchangeable Al was only half of what it was in the top $20 \mathrm{~cm}$ but remained virtually unchanged in the 20-40 and 40-60 $\mathrm{cm}$ layers.

\section{RESUMEN}

En dos siembras de sojas (variedad Júpiter), se estudió el efecto de la cal sobre el rendimiento y sobre los factores de acidez del terreno. Las sojas se sembraron en una arcilla Humatas, un Ultisol típico de la zona montañosa de Puerto Rico. La cal se aplicó a profundidades de 20,40 y $60 \mathrm{~cm}$. Otro tratamiento consistió de la aplicación de nitrato de calcio sobre la superficie del terreno.

Los datos recolectados en las dos cosechas revelaron correlaciones, muy significativas y significativas, entre el rendimiento de la soja y los factores de acidez del suelo en los $60 \mathrm{~cm}$ superficiales del perfil. Una ecuación lineal fue la que mejor describió los resultados.

Después de 33 meses de las aplicaciones de la cal, en las parcelas tratadas hasta $20 \mathrm{~cm}$ de profundidad, todavía se notaban aumentos en $\mathrm{pH}$ y en bases. El descenso en aluminio cambiable en la capa entre los 20 y $40 \mathrm{~cm}$ indicó movimiento de la cal a través del perfil hasta esta profundidad. 